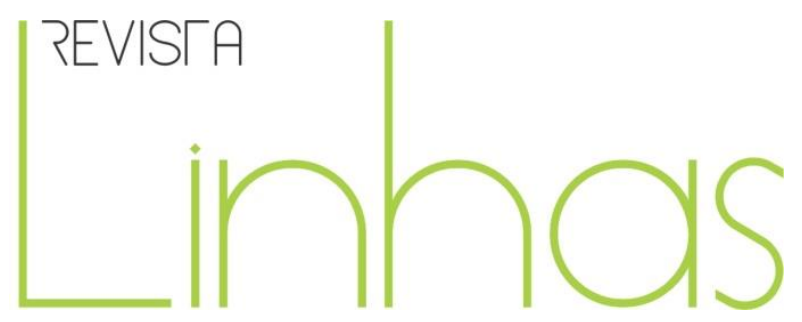

\title{
Analysis of the curricular framework for the Chemistry Licentiate Degree Course at the IFMT through DE ${ }^{1}$
}

\begin{abstract}
The curricular framework for a licentiate degree course has a direct influence on the type of teacher it will be qualifying. Thus, the objective of this study is to analyze the curricular framework for the Chemistry Licentiate Degree Course through DE by the IFMT Cuiabá-Bela Vista Campus in order to verify conformities with the national official documents and to indicate any adjustments for conformance. It is a document analysis from a qualitative approach that took place during 2016 and 2017. It was verified that the current matrix, as proposed in 2012, complies with the total hours required for the supervised internship, for complementary activities, and for practice as a curricular component, however, it does not comply with the 3,200 hours required for a licentiate degree course. It was found that the above matrix includes important and compulsory themes, such as the Brazilian Sign Language, inclusive education, youngster and adult education, and environmental education; but it does not include ethnic-racial issues, for example. One other aspect that was verified is the lack of discussions on the history, epistemology and/or philosophy of science, STS education, and education technologies. Therefore, the curricular framework analyzed complies in part with the national curriculum guidelines but needs some adjustments regarding the total course hours that could be achieved through the insertion of subjects of both specific and pedagogical types.
\end{abstract}

Keywords: Curriculum. Curriculum Guidelines. Teacher Training. Legislation.

Marcelo Franco Leão

Universidade Federal do Rio

Grande do Sul - UFRGS - Porto

Alegre/RS - Brasil

marcelo.leao@cfs.ifmt.edu.br

José Claudio Del Pino

Universidade Federal do Rio

Grande do Sul - UFRGS - Porto

Alegre/RS - Brasil

delpinojc@yahoo.com.br

Eniz Conceição Oliveira

Universidade do Vale do Taquari - Univates - Lajeado/RS - Brasil eniz@univates.br

\footnotetext{
Para citar este artigo:

LEÃO, Marcelo Franco; DEL PINO, José Cláudio; OLIVEIRA, Eniz Conceição. Analysis of the curricular framework for the Chemistry Licentiate Degree Course at the IFMT through DE. Revista Linhas. Florianópolis, v. 20, n. 42, p. 177-196, jan./abr. 2019.
}

\section{DOI: $10.5965 / 1984723820422019177$}

http://dx.doi.org/10.5965/1984723820422019177

\footnotetext{
${ }^{1}$ This study relied on financial subsidy of Call Notice 049/2017 from PROPES/IFMT and on support from the IFMT concerning the scholarship for the first author's doctoring (Call Notice 079/2016).
} 
Análisis del marco curricular para el curso de licenciatura en química en el IFMT a través de la Educación a Distancia

\begin{abstract}
Resumen
El marco curricular para un curso de licenciatura tiene una influencia directa en el tipo de profesor que se va a capacitar. Por lo tanto, el objetivo de este estudio es analizar el marco curricular para el Curso de Licenciatura en Química a través de educación a distancia por parte del Campus IFMT Cuiabá-Bela Vista para verificar la conformidad con los documentos oficiales nacionales e indicar los ajustes para el cumplimiento. Es un análisis de documento desde un enfoque cualitativo que se llevó a cabo durante 2016 y 2017. Se verificó que la matriz actual, como se propuso en 2012, cumple con las horas requeridas para la pasantía supervisada para actividades complementarias y prácticas como componente curricular, sin embargo, no cumple con las 3,200 horas requeridas para un curso de licenciatura. Se encontró que la matriz anterior incluye temas importantes y obligatorios, como el lenguaje de señas, la educación inclusiva, la educación de jóvenes y adultos y la educación ambiental, pero no incluye temas étnico-raciales, por ejemplo. Otro aspecto que se verificó fue la falta de discusiones sobre la historia, la epistemología y / o la filosofía de la ciencia, sobre el enfoque CTS y las tecnologías educativas. Por lo tanto, el marco curricular analizado cumple en parte con los lineamientos del currículo nacional, y necesita algún ajuste con respecto a las horas totales del curso que podrían lograrse a través de la inserción de asignaturas tanto de un tipo específico como pedagógico.
\end{abstract}

Palabras clave: Curriculum. Pautas Curriculares. Formación del Profesorado. Legislación.
Análise da estrutura curricular do Curso de Licenciatura em Química ofertado no IFMT na modalidade EaD ${ }^{2}$

\section{Resumo}

A estrutura curricular de um curso de licenciatura influencia diretamente no tipo de professor que por ela será formado. Assim, o objetivo deste estudo foi analisar a estrutura curricular do Curso de Licenciatura em Química, ofertado na modalidade EaD pelo IFMT Campus Cuiabá-Bela Vista, para verificar conformidades com os documentos oficiais nacionais e indicar ajustes necessários para sua adequação. Tratase de uma análise documental, com abordagem qualitativa, ocorrida nos anos de 2016 e 2017. Verificou-se que a atual matriz, proposta no ano de 2012, atende a carga horária para o estágio supervisionado, para as atividades complementares e para a prática como componente curricular, porém não atende às 3.200 horas exigidas para um curso de licenciatura. Constatou-se que essa matriz contempla importantes e obrigatórias temáticas, tais como Libras, educação inclusiva, educação de jovens e adultos e educação ambiental, porém não aborda as questões da diversidade étnico-racial, por exemplo. Outro aspecto verificado é a ausência de discussões sobre história, epistemologia e/ou filosofia da ciência, educação CTS e tecnologias educacionais. Portanto, a estrutura curricular analisada atende em partes as diretrizes curriculares nacionais, necessitando de uma adequação quanto à carga horária total do curso que pode ser realizada pela inserção de disciplinas tanto de natureza específica quanto pedagógica.

Palavras-chave: Currículo. Diretrizes Curriculares. Formação de Professores. Legislação.

\footnotetext{
${ }^{2}$ Esse estudo contou com o subsídio financeiro do Edital 049/2017 da PROPES/IFMT e com o apoio do IFMT, relativo a bolsa de estudo para o doutoramento do primeiro autor (Edital 079/2016).
} 


\section{Introduction}

It seems that one of the most evident problems in chemistry teaching is the inadequacy of the methodology adopted by teachers due to difficulties to select contents that are specific to teaching strategies and favor learning (LOPES et al, 2007). Such limitations, pointed out by researchers, may be related to the early training received.

This way, it is understood that the licentiate degree courses need to overcome the view of content centered training, since such mastery - though still important - is not currently sufficient for the teaching practice. In this sense, Lopes (2004)' reasoning is reinforced with the affirmation that a clear presentation of scientifically correct ideas by a teacher is not a condition for learning to take place. In other words, mastery of the reference contents is not sufficient to perform the teacher profession, since knowing "how" to teach such concepts is also necessary.

Along that line of thought, Silva \& Oliveira (2009) warn of the need to review and assess the teacher training process for the chemistry licentiate degree courses to meet their main objective, namely, training teachers to work in basic education. In the authors' view, it is expected that the course ensure that the licentiate receives knowledge of chemistry and of how to teach chemistry. However, the fact is that in the majority of courses, specific training is favored in detriment to pedagogical training, as if specific knowledge (chemistry) did not need to be linked to pedagogical knowledge.

That is why it is important to analyze a course's curriculum, because even the disciplines that comprise a curricular matrix are identified as discipline knowledge (TARDIFF, 2002). Those pieces of knowledge that cover several fields of knowledge originate from society are currently integrated in the institutions in the form of disciplines, within faculties and distinct courses. They rise from cultural tradition and the social knowledge producing groups.

In this sense, it is expected that the national curriculum of a course, especially those for teacher training, be constructed socially in order to include the conceptions and 
interpretations of the individuals they aim to qualify as professionals. In this respect, Heidelmann, Pinho \& Lima (2017) discuss that many teacher training course curricular matrices tend to favor specific technical over pedagogical knowledge due to the elaborators' wrong understanding that the chemistry teaching professional activity is directly linked to problem solving by applying theories and techniques.

According to Veiga (2004), when elaborating a Course Pedagogical Project (CPP) in which the curricular matrix is defined to direct the training process, the Higher Education Institution ( $\mathrm{HEI}$ ) must go beyond simply grouping the contents and activities it intends to offer. The author warns that such curriculum must be elaborated in such a way that it is experienced at all training instances according to the HEl's proposed intention.

Researchers Zucco, Pessine \& Andrade (1999), have alerted that, since the turn of the century, the chemistry licentiate degree course curricula are overflowing with informative rather that training contents, which was later confirmed by Report Nr. 1.303 CNE/CE from November 6, 2001 (BRASIL, 2001). That is, most courses are training professionals with outdated or insufficient knowledge to act in society responsibly, be it as teachers or as citizens.

To revert this situation, Veiga (2004) suggests in his studies that the licentiate courses organize the curricular matrix in an integrated fashion between reference knowledge and pedagogical concepts, preferably in an interdisciplinary manner. He further states that "the frontiers between the curricular components are technical, since the contents hold an open relation between them. With integration, hierarchy is dissipated and a common teaching practice is established" (VEIGA, 2004, p. 67).

In other words, a licentiate course that pursues interdisciplinarity as a training principle must be scripted on curricular flexibilization and on the posture of the guidance stated in the CPP. This way, chemistry teachers early training shall be scripted in the integration of all types of knowledge and not in hierarchization.

Along this line of thought, Heidelmann, Pinho \& Lima (2017, p. 262) state that: "The pedagogical project must be comprehended within its political dimension, by starting from a reflection of daily life, a commitment that is collectively defined with 
citizenship preparation". What the authors advocate is the need to consider the real circumstances. that training must be humanistic, making lessons for life possible, as well as establishing relations between theory and reality, between chemistry and life, and thus maintain the complementation between the pedagogical and specific training.

From the above, the objective of this study is to analyze the curricular framework for the Chemistry Licentiate Degree Course through DE by the IFMT Cuiabá-Bela Vista Campus, taking as reference the CPP documents in order to verify conformities with the current educational legislation, such as official guidelines that regulate early teacher training in the country.

Carrying out this study is justified since, as Heidelmann, Pinho \& Lima (2017) state, the curricular framework a course adopts is a determining factor in the construction of teacher identity and has direct influence in the professional qualified by the course. Furthermore, the training process will reflect upon basic education schools, in the activity of the chemistry teachers who qualify at the course. Therefore, it is important to study such curricular framework to understand the training realities of future chemistry teachers.

This text is organized into five sections to facilitate reading. The second section presents some aspects of the current legislation and the official guidelines for licentiate degree courses. The third section presents how the document analysis of the CPP for the course chosen for the investigation was carried out. In the fourth, the data are presented and discussed, and the fifth covers the final considerations attained from this study.

\section{What the official documents advocate for the licentiate degree courses}

As a result of the changes proposed by Law Nr. 9.394 from 1996, which establishes the National Education Guidelines and Foundations (BRASIL, 1996), a trend is observed towards more generalist training with curricula including themes that would allow to reflect upon ethics, citizenship and social responsibility. It also proclaims the opening up 
and flexibilization of the teacher training curricular matrices in order that such demand for humanistic training be included.

Towards this sense, one other important document was elaborated by the National Education Counsel, via the Higher Education Chamber in 2001, through Report Nr. 1.303 to establish the National Curricular Guidelines for Chemistry Courses in Brazil (BRASIL, 2001). This official document proposes that training institutions need to rethink curricular organization to adjust to the new society's paradigm in order to prepare acting, questioning, critical professionals capable of relating knowledge from beyond their area of reference.

As the above mentioned report instructs,

the Chemistry Licentiate should receive generalist training that is solid and encompassing of contents from the several Chemistry fields, adequate preparation for the pedagogical application of knowledge and experiences of Chemistry and related areas in their professional activity in basic and elementary education. (BRASIL, 2001, p. 4)

Those guidelines instruct on the expected chemistry teachers' personal and professionals skills regarding the chemistry licentiate training, chemistry comprehension, the pursuit of information, communication and expression, chemistry teaching and the profession. As to the general framework, the document instructs the courses to try to avoid knowledge compartmentalization and seek to integrate chemistry knowledge with related areas aimed at interdisciplinarity (BRASIL, 2001).

Regarding curricular contents, the guidelines establish for basic contents that concepts of mathematics, physics and chemistry are indispensable. For specific contents, the document establishes that they are professional contents, essential to the development of competences and skills that are inherent to chemistry teachers. For complementary contents, those that are essential to a humanistic training. Furthermore, the guidelines instruct on what complementary activities actually are and on attending supervised internship (BRASIL, 2001). 
According to Art. 61 of the National Education Law of Guidelines and Foundations in Brazil (Lei de Diretrizes e Bases - LDB): Supervised internships comprise preprofessional practice activities performed in actual work situations under the terms of current legislation (BRASIL, 1996). According to the definitions in Law Nr. 11.788 from September 25, 2008 that details student internship, it states that the supervised internship included as the educational route in the Course Pedagogical Project (CPP), is an action aimed at learning competences that belong to the professional activity for which the student is training (BRASIL, 2008a).

Article $9^{\circ}$ of Federal Decree Nr. 5.626 from December 22, 2005 establishes the inclusion of sign language as a compulsory curricular discipline, initially in Special Education, Phonoaudiology, Pedagogy and Language courses, progressively extending to the other licentiate degree courses in the country (BRASIL, 2005).

According to Resolution Nr. 02/2012, one of the objectives of the National Curricular Guidelines for Environmental Education is to instruct the teacher training courses for Basic Education (BRASIL, 2012a). Thus, it is the duty of the licentiate degree courses to qualify education professionals to develop teaching practices that integrate environmental education with their area of knowledge to favor students' comprehension of the relations between the environment and social practices with aims to develop new habits regarding production and consumption.

In search of consolidating national standards for teacher training for basic education, on July 1, 2015, Resolution Nr. 2 was approved, which defines the National Curricular Guidelines for early training at the higher education level (licentiate degree courses, pedagogical training courses for graduates, and second licentiate degree courses) and for continuous training (BRASIL, 2015).

The resolution was elaborated from the observation of the precepts in articles 61 to 67 and article 87 of Law Nr. 9.394 from 1996, that detail the training of mastership professionals, Decree Nr. 6.755 from January 29, 2009, Resolutions Nr. 1 CNE/CP from February 18, 2002, CNE/CP Nr. 2 from February 19, 2002, CNE/CP Nr. 1 from May 15, 2006, CNE/CP Nr 1 from February 11, 2009, CNE/CP Nr. 3 from June 15, 2012, and Resolutions Nr. 2 
CNE/CEB from April 19 1999, and CNE/CEB Nr. 2 from February 25, 2009, the National Basic Education Curricular Guidelines, as well as Report Nr. 2 CNE/CP from June 9, 2015.

Article 13, $\S 1$ of the above resolution establishes 3,200 (three thousand, two hundred) compulsory hours of effective academic work for early higher teacher training. The same line establishes that the courses have a minimum duration of 8 (eight) semesters or 4 (four) years. The same article, but in $\S 2$, assures that licentiate degree courses include specific training to value diversity and contribute towards respect for ethnic-racial, gender, generation range, social class, religious, special needs, sexual diversity differences, among others (BRASIL, 2015).

Those are some pieces of information the national official documents contain that regulate the operation of licentiate degree courses in the country. It needs pointing out here that along the analysis of the CPP of the investigated course further information will be presented, since this topic does not end here.

\section{Methodological Procedures}

This study is configured as a descriptive document analysis from a qualitative approach that was carried out during 2016 and 2017. The object of this study is the curricular framework for the Chemistry Licentiate Degree Course through DE by the IFMT Cuiabá-Bela Vista Campus. The investigation of this object required the employment of the document analysis method. This type of research involves several forms of registry as the primary source of information (GIL, 2010).

This document analysis is a cutout of the doctoring research developed in the Science Education Stricto Sensu Post-Graduation Program: Life and Health Chemistry offered by the Federal University of Rio Grande do Sul (UFRGS) - Saúde Campus in Porto Alegre-RS.

According to Roehrs (2013), the analysis of discourse identified from the documents allows access to a given reality under a different perspective and contributes to its validation by triangulating data collection strategies. In addition to expressing the 
reality of a context and the facts, it is necessary to perceive that they are human constructions, with a practical purpose, aimed at a determined use and access.

According to Gil (2010) some procedures are suggested for the analysis and interpretation process of information sourced from document research. The nine steps suggested by the author may be summed as: choice and organization of the information sources; a detailed study with analytical description; treatment and interpretation.

Firstly, a bibliographical ascertainment was carried out of the current educational legislation and official guidelines that instruct the construction of Chemistry Licentiate Degree courses in a nationwide scope, such as Resolution Nr. 2 from July 1, 2015 (BRASIL, 2015), that defines the National Curricular Guidelines for Basic Education Teacher Training in Brazil.

The documents used for this analysis were the Pedagogical Project of the Chemistry Licentiate Degree Course, federal laws and official guidelines. The referred documents were obtained from website pages of the Higher Education Institution ( $\mathrm{HEI}$ ) offering the investigated course and of the Ministry for Education, Culture and Technology (MEC), more specifically the National Education Counsel that offers free access for consultation.

It should be informed that consent was signed by those in charge of the course (UAB/IFMT coordinator, IFMT Cuiabá-Bela Vista Campus dean, and the coordinator of the respective course), which allows the research to be carried out providing access to any necessary document.

Result interpretation was made in such a way that all the information contained in the CPP of the course was related with the authors who debated the curricular framework of the Chemistry Licentiate Degree courses and with the national official documents. 


\section{Results and Discussion}

The current curricular framework of the investigated course is shown in Chart 1. It is the second curricular framework version of the course that was approved through the CPP in 2012. A third version of the course curricular matrix is in the elaboration phase.

Chart 1: UAB/IFMT Chemistry Licentiate Degree Course Matrix

\begin{tabular}{|c|c|c|c|c|c|}
\hline \multirow[b]{2}{*}{ Curricular Component } & \multirow[b]{2}{*}{ Sem } & \multicolumn{4}{|c|}{ Class Hours } \\
\hline & & SCN & PCC & SI & SA \\
\hline Introduction to Distance Education & 1st & 60 & & & \\
\hline General Chemistry I & 1st & 100 & & & \\
\hline Scientific Methodology & $1 \mathrm{st}$ & & 60 & & \\
\hline Socio-Anthropological Basics of Education & 1st & 60 & & & \\
\hline Mathematics Basics & 1st & 60 & & & \\
\hline Portuguese & 1st & 60 & & & \\
\hline Philosophy of Education & 1st & 60 & & & \\
\hline Differential and Integral Calculus I & 2nd & 60 & & & \\
\hline Linear Algebra and Analytic Geometry & 2nd & 60 & & & \\
\hline General Chemistry II & 2nd & 80 & & & \\
\hline Chemistry and Environmental Education & 2nd & 80 & & & \\
\hline General Biology & 2nd & 80 & & & \\
\hline Psychology of Education & 2nd & 60 & & & \\
\hline Organic Chemistry I & 2nd & 80 & & & \\
\hline Statistics Applied to Chemistry Basics & 3 rd & 40 & & & \\
\hline Differential and Integral Calculus II & 3 rd & 60 & & & \\
\hline Organic Chemistry II & 3 rd & 60 & & & \\
\hline Educational Legislation and Guidelines & 3 rd & 60 & & & \\
\hline Fundamental Physics I & 3 rd & 60 & & & \\
\hline Biochemistry Basics & 3 rd & 60 & & & \\
\hline General Didactics & 3 rd & & 80 & & \\
\hline Complementary Activities & $3 r d$ & & & & 60 \\
\hline Physic-Chemistry I & 4th & 80 & & & \\
\hline Fundamental Physics II & 4th & 80 & & & \\
\hline Inorganic Chemistry I & 4th & 80 & & & \\
\hline Learning Planning and Assessment & 4th & & 60 & & \\
\hline Chemistry Teaching Methodology & 4th & & 60 & & \\
\hline Supervised Internship I & 4th & & & 100 & \\
\hline Complementary Activities & 4th & & & & 60 \\
\hline Physic-Chemistry II & 5th & 80 & & & \\
\hline Inclusive Education & 5 th & & 60 & & \\
\hline Inorganic Chemistry II & 5th & 60 & & & \\
\hline Optional Discipline* & 5th & 60 & & & \\
\hline Supervised Internship II & 5th & & & 140 & \\
\hline Qualitative Analytical Chemistry & 5th & 80 & & & \\
\hline Complementary Activities & 5th & & & & 40 \\
\hline Quantitative Analytical Chemistry & 6th & 80 & & & \\
\hline Instrumental Analysis & 6th & 60 & & & \\
\hline
\end{tabular}




\begin{tabular}{|l|c|c|c|c|c|}
\hline Modern Chemistry & 6th & 40 & & & \\
\hline $\begin{array}{l}\text { Brazilian Sign Language (Linguagem Brasileira de Sinais - } \\
\text { LIBRAS) Basics }\end{array}$ & 6 th & & 60 & & \\
\hline Supervised Internship III & 6th & & & 160 & \\
\hline Youngster and Adult Education & 6th & & 60 & & \\
\hline Complementary Activities TOTAL & 6th & & & & 40 \\
\hline \multicolumn{1}{|c|}{ TOM } & $\mathbf{1 , 9 4 0}$ & $\mathbf{4 4 0}$ & $\mathbf{4 0 0}$ & $\mathbf{2 0 0}$ \\
\hline
\end{tabular}

SCN: Scientific-Cultural Nature; PCC: Practice as Curricular Component; SI: Supervised Internship; SA: Academic-Scientific-Cultural Activities.

*Transition Metals Chemistry or Chemistry Applied to the Foodstuffs Area, or Radioactivity or Technical and Scientific English.

Source: Own elaboration based on the Course Pedagogical Project (2012).

It can be observed in Chart 1 that this course was organized to comprise 1,940 (one thousand nine hundred and forty) hours of curricular contents of a scientific-cultural nature; 440 (four hundred and forty) hours of practice as curricular component; 200 (two hundred) hours of academic-scientific-cultural activities; and 400 (four hundred) hours of supervised internship, which begins to be developed after the fourth semester.

It can be perceived that the total hours for the course is of 2,980 (two thousand nine hundred and eighty) spread over 6 (six) semesters and lasting 3 (three) years, which is in conformity with the legislation for operation of licentiate degree courses at at the time, i.e., a minimum 2,400 (two thousand four hundred) hours according to CNE/CES Resolution Nr. 2 (BRASIL, 2007). However, the course needs to adjust the total hours immediately to comply with the 3,200 (three thousand two hundred) hours and duration of 8 (eight) semesters or 4 (four) years, as established by Resolution Nr. 2 (BRASIL, 2015).

Article 22 in the above mentioned resolution also establishes that the teacher training courses that are already operating must adapt to the prerogatives in this Resolution within 2 (two) years as from its date of publication. That is, the adjustment period has expired and the course still has no new approved CPP.

Regarding the supervised internships, it was found to total 400 (four hundred) hours divided into three stages: Supervised Internship I, Supervised Internship II, Supervised Internship III (IFMT, 2012). The first stage is intended to insert the undergraduate in the school routine by making observations about the structure and operation of the school and the pedagogical practice of trained teachers. 
The second stage is aimed at planning Science classes for the gth year of Elementary Education and preparing didactic-pedagogical materials, in addition to developing a pedagogical intervention project. The third stage is when teaching takes place in the Intermediate Education Chemistry discipline aimed at learning the competences that belong to the professional activity for which the student is training. The manner in which the supervised internship is proposed conforms with Law Nr. 11.788 (BRASIL, 2008a).

According to Resolution Nr. 2 from July 1, 2015 (BRASIL, 2015) that defines the National Curricular Guidelines for early training at the higher education level, its Art. 13 establishes that the minimum total hours to complete the supervised internship is of 400 (four hundred), which are to be dedicated to the specific training area to work in basic education, considering in sporadic cases related areas, as long as it is included in and authorized by the institution's course project.

As determined in the CPP (IFMT, 2012), the academic-scientific-cultural activities total 200 (two hundred) hours. Those complementary activities conform with the parameters defined in Art. 13, IV of Resolution Nr. 2 (BRASIL, 2015) that establishes a minimum of 200 (two hundred) hours of further enhancement theoretical-practical activities. Those activities are carried out according to the students' interest, by means of scientific initiation, teaching initiation, extension, monitoring, among others, as per the institution's course project.

Concerning the development of practice as a curricular component, the course covers a total of 440 (four hundred and forty) hours. The curricular components that involve education practice are concentrated in the second half of the course, not including a single discipline up to the second semester. Below are the disciplines considered to be practice as a curricular component: Scientific Methodology (1st), General Didactics (3rd), Chemistry Teaching Methodology (4th), Learning Planning and Assessment (4th), Inclusive Education (5th), Brazilian Sign Language Basics (6th), and Youngster and Adult Education (6th). 
Article 13, I of Resolution Nr. 2 (BRASIL, 2015) establishes a minimum of 400 (four hundred) hours of practice as a curricular component to be distributed throughout the training process. In the investigated course, the minimum total hours requirement for practice as a curricular component is met and even surpassed, but the instruction to be distributed throughout the course is not followed and they are concentrated in the latter semesters. However, Heidelmann, Pinho \& Lima (2017, p. 263) point out that this "practice" must be understood as being the activities performed by the undergraduates "within the scope of teaching and that should take place from early on in teacher training all the way to the end of the process".

It is observed that this course contains predominantly curricular components of scientific-cultural nature -1,940 (one thousand nine hundred and forty) hours of basic contents (mathematics, chemistry, physics), and essential specific contents for the development of competences and skills for the profession (BRASIL, 2001).

This need must be agreed so that the professionals trained by the course have the theoretical and practical foundation in their reference area. However, Silva \& Oliveira (2009) warn that the majority of training institutions adopt a large focus on technical reasoning, forgetting they are training chemistry teachers. It is as if it was not the duty of the training teachers for those disciplines to link all the specific knowledge to the way of teaching it.

The curricular component Educational Legislation and Guidelines (3rd semester) covers the basic education framework and operation, the education laws and guidelines that direct the Brazilian education system. However, it was not possible to find in the current curricular framework as a whole any instance that would allow to reflect upon education in a wholesome fashion, upon the historical hindsight of the Brazilian education system, as well as upon paradigm shifts that resulted in contemporary education. Furthermore, Heidelmann, Pinho \& Lima (2017) verified in their studies about the lack of discussions of the social role of chemistry teaching throughout the early and continued teacher training. 
It is also observed that the curricular matrix included Philosophy of Education (1st semester), but does not include throughout early teaching discussions about History, Epistemology and/or Philosophy of Science, neither the Science, Technology and Society (STS) education field . In his studies, Bachelard (1996) advocates that the conception of science that teachers assume is a determining factor in their manner of acting. That is, it is essential that a chemistry teacher training course covers discussions that lead to students forming conceptions of science, as this will favor future teachers' comprehension of the science teaching and learning processes.

The above mentioned suggestions for adjustments are aimed at a curricular profile that remains scientific, albeit more humanistic; towards this sense of making that training process a space in which the construction of knowledge occurs in relation to its historic context, in compliance with Report 1.303 (BRASIL, 2003). This way, the "how" and "how intensely" scientific productions occur will be considered, thus overcoming the positivist paradigm in which knowledge of or in science is taken as absolute and dogmatic.

The inclusion of the disciplines Inclusive Education (5th semester), Youngster and Adult Education (YAE) and Brazilian Sign Language (6th semester) conforms to and partly meets that established by Resolution Nr. 2 (BRASIL, 2015). Also observed is the insertion of the discipline Brazilian Sign Language (Libras) Basics that meets what is established in Decree 5.626 (BRASIL, 2005). The presentation of the discipline Chemistry and Environmental Education (2nd semester) in the curriculum meets the training instructions advocated in Resolution Nr. 02 (BRASIL, 2012a).

The offering of a discipline on the YAE (6th semester) is timely for this training process that prepares professionals to work within a real context. However, it must be considered that education for diversity is much broader. A reminder is worthy of three other education specificities found in the state of Mato Grosso, namely, Outdoor Education, Indigenous School Education and Quilombola School Education, backed respectively by Resolutions Nr. 1 from April 3, 2002 (BRASIL, 2002), Nr. 5 from June 22, 2012 (BRASIL, 2012b) and Nr. 08 from November 20, 2012 (BRASIL, 2012C). 
Likewise, it is noticed that this course does not include discussions on respect for ethnic-racial differences as indicated in Laws Nr. 10.639, (BRASIL, 2003) and Nr. 11.645 (BRASIL, 2008b) that describe compulsory training to be taught in public and private Elementary and Intermediate Education of history and Afro-Brazilian and Indigenous culture studies. One important characteristic to be considered, as advocated by Veiga (2004) and by Silva \& Oliveira (2009), is the fact that the licentiate degree courses train teachers to work in basic education.

One other suggestion of adjustment to the curricular framework of this course concerns the use of educational technologies. The insertion of information and communication technologies in educational practices is a necessity within the current context. However, teachers will only feel confident to utilize technological media in class if they have been prepared. Furthermore, the course itself makes use of technological tools for DE teaching.

This finding goes to corroborate what Zucco, Pessine \& Andrade (1999) have verified, that the chemistry licentiate degree courses have been covering outdated knowledge for a long time, which Silva \& Oliveira (2009, p. 45) have warned about, that in the majority of those courses there is "a lack of contents relative to information and communication technologies".

One other shortcoming that was observed in the current curricular framework is the offering of optional teaching disciplines in the chemistry area. The four optional discipline choices are of specific knowledge, that is, they do not follow the guideline instructions for chemistry courses to correlate chemistry specific contents with general contents in the curriculum aiming towards interdisciplinarity (BRASIL, 2001). Veiga (2004) also advocates the need to cross the technical boundaries between disciplines, since the contents are not isolated, but maintain an open relation between them.

Furthermore, it was observed that the course does not include the development of the Course Completion Paper (CCP) in its curricula framework, which is not in favor of encouraging research, an indispensable element for contemporary teachers. Nevertheless, the current curricular matrix offers the scientific methodology discipline. 
Those two lacking items (optional teaching aimed disciplines and CCP) were also verified in the study by Silva \& Oliveira (2009).

There will always be room for changes and adjustments to a course's curricular framework, but curricular integration should not be thought of simply as a result of inserting disciplines solely to meet the official guidelines, but that they be interlinked in the training of creative, inquisitive, socially committed chemistry teachers who are not mere information hoarders, but professionals who know how to swiftly seek it to build the necessary items of knowledge for each situation.

\section{Final Considerations}

Upon analyzing the curricular framework for the Chemistry Licentiate Degree Course through DE by the IFMT Cuiabá-Bela Vista Campus with the support of official documents, it was possible to ascertain the conformities and gaps to be adjusted in order that this early teacher training qualify autonomous, trained professionals as is expected in contemporary education.

The conformities pertain to the supervised internship total hours, complementary activities and practice as a curricular component. The current curricular matrix includes important, compulsory issues, such as Brazilian Sign Language, inclusive education, youngster and adult education, and environmental education. However, it contains gaps related to ethnic-racial diversity, history, epistemology and/or philosophy of science, STS, and education technologies.

It is deemed important that a chemistry licentiate degree course provide the development of the fundamental skills for teachers to relate the contents of reference (chemistry concepts), teaching strategies, and reality (daily life) in order to favor learning. This way, pedagogical tools are developed that are appropriate to establish the connections between chemistry and life, which will lead students to relate the contents being studied with the other fields of knowledge. 
Towards the end of this study, it is possible to consider that the curricular framework studied meets the current legislation and official guidelines in part, that the course includes issues that are indispensable to train teachers; however, it needs to be adjusted with regards to the total hours, which may be attained with the insertion of disciplines of both specific and pedagogical natures.

The presupposition that licentiate degree courses need to overcome the view of content-based training highlights the need for a revision and assessment of the course's pedagogical project, in view that the main objective of the chemistry licentiate degree courses is to qualify teachers to work in basic education. Such curricular adjustment is founded on scientific and humanistic bases of teacher knowledge, regardless of the modality, since every licentiate degree course, either presential or distance, seeks to meet the training demands. Thus, it is expected that chemistry teacher early training be increasingly further studied, debated and known so that this process may prepare professionals who are qualified to teach chemistry. 


\section{References}

BACHELARD, Gaston. O Novo espírito científico. Rio de Janeiro: Tempo Brasileiro, 1996.

BRASIL. Conselho Nacional de Educação. Parecer N 1.303 CNE/CE, de 06 de novembro de 2001. Diretrizes Curriculares para Cursos de Química, Bacharelado e Licenciatura Plena. Brasília: MEC, [2001]. Disponível em:

<http://portal.mec.gov.br/cne/arquivos/pdf/CES1303.pdf >. Acesso em: 23 ago. 2016.

BRASIL. Conselho Nacional de Educação. Resolução N 1 CNE/CEB, de 3 de abril de 2002. Brasília: MEC, [2002]. Institui Diretrizes Operacionais para a Educação Básica nas Escolas do Campo. Disponível em: <http://portal.mec.gov.br/cne/arquivos/pdf/CEB012002.pdf>. Acesso em: 11 out. 2016.

BRASIL. Conselho Nacional de Educação. Resolução Nº 2 CNE/CES, de 18 de junho de 2007. Dispõe sobre carga horária mínima e procedimentos relativos à integralização e duração dos cursos de graduação, bacharelados, na modalidade presencial. Brasília: MEC, [2007]. Disponível em: <http://portal.mec.gov.br/cne/arquivos/pdf/2007/rces002_07.pdf>. Acesso em: 11 out. 2016.

BRASIL. Conselho Nacional de Educação. Resolução N 2 CNE/CP, de 15 de junho de 2012. Estabelece as Diretrizes Curriculares Nacionais para a Educação Ambiental. Diário Oficial da União, Brasília, n. 116, seção 1, p. 70, 18 jun. 2012 Brasília: MEC, [2012a].. Disponível em: <http://conferenciainfanto.mec.gov.br/images/pdf/diretrizes.pdf>. Acesso em: 23 ago. 2016.

BRASIL. Conselho Nacional de Educação. Resolução No 5 CNE/CEB, de 22 de junho de 2012. Define Diretrizes Curriculares Nacionais para a Educação Escolar Indígena na Educação Básica. Brasília, 2012. Brasília: MEC, [2012b]. Disponível em: <http://www.educadores.diaadia.pr.gov.br/arquivos/File/pdf/resolucaoeduc_campo.pdf>. Acesso em: 23 ago. 2016.

BRASIL Conselho Nacional de Educação. Resolução N $^{\circ} 8$ CNE/CEB, de 20 de novembro de 2012. Define Diretrizes Curriculares Nacionais para a Educação Escolar Quilombola na Educação Básica Brasília, 2012. Brasília: MEC, [2012C]. Disponível em: <http://www.crmariocovas.sp.gov.br/Downloads/ccs/concurso_2013/PDFs/resol_federal 8_12.pdf>. Acesso em: 23 ago. 2016.

BRASIL. Conselho Nacional de Educação. Resolução $\mathbf{N}^{\circ} 2 \mathrm{CNE} / \mathrm{CP}$, de $1^{\circ}$ de julho de 2015. Define as Diretrizes Curriculares Nacionais para a formação inicial em nível superior (cursos de licenciatura, cursos de formação pedagógica para graduados e cursos de segunda licenciatura) e para a formação continuada. Brasília: MEC, [2015]. Disponível em: <http://pronacampo.mec.gov.br/images/pdf/res_cne_cp_02_03072015.pdf >. Acesso em: 11 out. 2016. 
BRASIL. Decreto Federal $\mathbf{N}^{\circ}$ 5.626, de 22 de dezembro de 2005. Regulamenta a Lei no 10.436, de 24 de abril de 2002, que dispõe sobre a Língua Brasileira de Sinais - Libras. Brasília, DF: Presidência da República, 2005. Disponível em:

<http://www.planalto.gov.br/ccivil_03/_ato2004-2006/2005/decreto/d5626.htm>. Acesso em: 11 out. 2016.

BRASIL. Lei $\mathbf{N}^{\circ}$ 9.394, de 20 de dezembro de 1996. Estabelece as diretrizes e bases da educação nacional. Brasília, 20 dez. 1996. Disponível em:

<http://www.planalto.gov.br/ccivil_03/leis/L9394.htm>. Acesso em: 15 set. 2016.

BRASIL. Lei No 10.639, de o9 de janeiro de 2003. Diário Oficial da União. Brasília, DF, 10 de janeiro de 2003. Disponível em:

<http://www.planalto.gov.br/ccivil_03/leis/2003/L10.639.htm>. Acesso em: 15 set. 2016.

BRASIL. Lei № 11.788, de 25 de setembro de 2008. Dispõe sobre o estágio de estudantes. Diário Oficial da União, Brasília, DF, 26 de setembro de 2008a. Disponível em:

<http://www.planalto.gov.br/ccivil_03/_ato2007-2010/2008/lei//11788.htm>. Acesso em: 08 out. 2016.

BRASIL. Lei N ${ }^{\circ}$ 11.645, de 10 de março de 2008. Diário Oficial da União, Brasília, DF, 11 de março de 2008b. Disponível em: <http://www.planalto.gov.br/ccivil_03/_ato20072010/2008/lei/l11645.htm>. Acesso em: 11 out. 2016. GIL, Antônio Carlos. Como elaborar projeto de pesquisa. 5. ed. São Paulo: Atlas, 2010.

HEIDELMANN, Stephany Petronilho; LIMA, Maria Celiana Pinheiro; PINHO, Gabriela Salomão Alves. Caminhos e descaminhos da formação docente: Uma análise dos Projetos Pedagógicos de Cursos de Licenciatura em Química no Rio de Janeiro. Química Nova na Escola (online), v. 39, n. 3, p. 261-267, 2017. Disponível em: <http://qnesc.sbq.org.br/online/qnesc39_3/07-EA-06-16.pdf>. Acesso em: 16 nov. 2016.

IFMT. Projeto pedagógico de curso de licenciatura em química. Cuiabá: Instituto Federal de Mato Grosso, 2012.

LOPES, Joaquim Bernardino. Aprender e ensinar física. Braga: Fundação Calouste Gulberskian; Fundação para a Ciência e a Tecnologia, 2004.

LOPES, Cesar Valmor Machado; KRÜGER, Verno; DEL PINO, José Claudio; SOUZA, Diogo Onofre Gomes de. Concepções de professores de química sobre a natureza do conhecimento científico. Acta Scientiae (ULBRA), v. 9, p. 3-16, 2007. Disponível em: <http://www.periodicos.ulbra.br/index.php/acta/article/view/92>. Acesso em: 16 nov. 2016.

ROEHRS, Marfa Magali. Licenciatura em ciências biológicas: uma análise dos saberes de referência e pedagógicos na formação de professores para os anos finais do Ensino Fundamental. 2013. Dissertação (Mestrado em Educação) - Universidade Federal de Mato Grosso, Programa de Pós-Graduação em Educação Cuiabá, 2013. 
SILVA, Camila Silveira da; OLIVEIRA, Luiz Antonio Andrade de. Formação inicial de professores de química: formação específica e pedagógica. In: Roberto Nardi. (Org.). Ensino de ciências e matemática I: temas sobre a formação de professores. 1. ed. São Paulo: Cultura Acadêmica, 2009, v. 1, p. 43-57.

TARDIF, Maurice. Saberes docentes e formação profissional. Petrópolis: Vozes, 2002. VEIGA, Ilma Passos Alencastro. Educação básica e educação superior: projeto político pedagógico. Campinas: Papirus, 2004.

ZUCCO, César; PESSINE, Francisco Benedito Teixeira; ANDRADE, Jailson Bittencourt de. Diretrizes curriculares para os cursos de química. Química Nova, Brasil, v. 22, n.3, p. 454461, 1999. 